\title{
CONNECTIVE TISSUE ACTIVATION
}

\section{Composition and Actions of a Human Platelet Autacoid Mediator}

\author{
C. WILLIAM CASTOR, JAMES C. RITCHIE, CHARLES H. WILLIAMS, JR., MARY E. SCOTT, \\ SHERRY L. WHITNEY, STEPHEN L. MYERS, TOD B. SLOAN, and BYRON E. ANDERSON
}

Connective tissue activating peptide-III (CTAPIII) isolated from human platelets is a potent mitogen for human connective tissue cells in culture in addition to stimulating glycosaminoglycan synthesis, glucose consumption, and lactate formation. The amino acid composition of apparently homogeneous CTAP-III was determined, confirming the presence of two disulfide links and providing a calculated molecular weight of 11,633 daltons. Comparison of the mitogenic activity of serum and plasma-serum suggests that CTAP-III is a major mitogenic component of human serum. Seventeen strains of human connective tissue cells (synovial, cartilage, dermal and thyroid) incorporated $\left[{ }^{3} \mathrm{H}\right]$-thymidine

From The Department of Internal Medicine and the Rackham Arthritis Research Unit, the University of Michigan Medical School, and the Veterans Administration Hospital, Ann Arbor, Michigan, and the Departments of Biochemistry, Otolaryngology and Maxillofacial Surgery, Northwestern University Medical and Dental Schools, Chicago, Illinois.

Supported by USPHS Grant AM-10728, by the Michigan Chapter, Arthritis Foundation, by the Medical Research Service of the Veterans Administration, and by USPHS Grants AM-16326 and AM-70787.

William Castor, MD: Professor of Internal Medicine; James C. Ritchie, BS: Research Associate; Charles H. Williams, Jr., PhD: Associate Professor of Biochemistry; Mary E. Scott: Research Assistant; Sherry L. Whitney, BS: Research Assistant; Stephen L. Myers, MD: Postdoctoral Fellow; Tod B. Sloan, PhD: Associate Professor of Biochemistry; Byron E. Anderson, PhD: Associate Professor of Biochemistry.

Address reprint requests to C.W. Castor, MD, Rackham Arthritis Research Unit, University of Michigan Medical School, Ann Arbor, Michigan 48109.

Submitted for publication May 31, 1978; accepted in revised form November 16, 1978. at up to 30 times control at levels under the influence of microgram quantities of CTAP-III and caused detectable increases in thymidine incorporation at levels as low as 10-29 $\mathrm{ng} / \mathrm{ml}$. Prostaglandin $\mathbf{E}_{1}(0.01 \mu \mathrm{g} / \mathrm{ml})$ and dibutyryl cyclic AMP $(25 \mu \mathrm{g} / \mathrm{ml})$ potentiated the glycosaminoglycan stimulating effect of CTAP-III, but not its mitogenic effect. Cycloheximide and actinomycin D blocked the biologic actions of CTAP-III. Cortisol and penicillamine had little effect on the mitogenic activity of CTAP-III, whereas antirheumatic agents such as acetylsalicylic acid and phenylbutazone opposed the mitogenic activity when added to cultures at clinically relevant concentrations. A weak antiheparin factor secreted by platelets, low affinity platelet factor $4\left(\mathrm{LA}^{-}-\mathrm{PF}_{4}\right)$, was shown to be similar to CTAP-III in biologic actions, electrophoretic mobility, amino acid composition, and antigenic determinants.

Human synovial cells have been "activated" in vitro both by incubation with living lymphocytes, thrombocytes, and polymorphonuclear leukocytes and by incubation with extracts of these blood cells (1-3). Connective tissue activation was defined as a constellation of metabolic events occurring during the reparative phase of inflammation, including stimulation of cellular energy metabolism, glycosaminoglycan (GAG) synthesis, proliferation, and collagen synthesis (4). Protein moieties extractable from leukocytes and platelets that stimulate such "activation" were termed connective tissue activating peptide(s) [CTAP (s)]. The 
ISOLATIOH OF CTAP-III FROM HUMAN PLATELETS

Stage I Extract hashed, frozen human platelets with 10 volumes of 95\% ETHANOL: $5 \% 1.25 \mathrm{~N} \mathrm{HCL} \mathrm{FOR} 1$ HR AT $21^{\circ} \mathrm{C}$

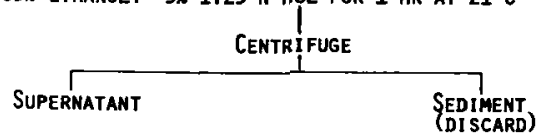

Stage II Add 3 volumes of acetome FOR 1 HR AT $21^{\circ} \mathrm{C}$
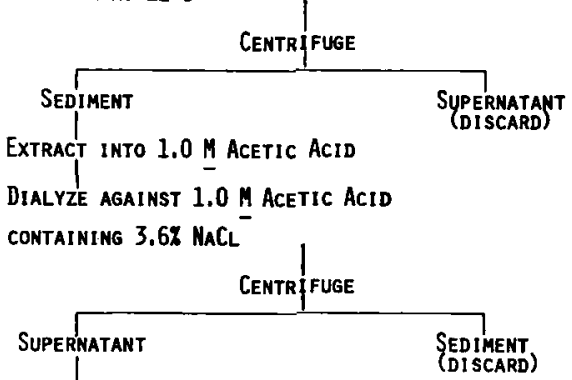

Stage III Gel Permeation Chromatography on Sephacryl S-200 Columw,

RETAIN RETARDED PROTEIN FRACTION CORRESPONDING TO Cytochrome C elution Volume

$\downarrow$

Stage IV Ion exchange chromatography hith CM-Sephadex C-50 Retain fraction eLUting WITH $0.1 \mathrm{M} \mathrm{PO}_{4}$, PH 6.0, 0.25 M NaCL

Figure 1. Isolation of CTAP-III from human platelets. Stages III and IV may have to be executed twice in order to obtain CTAP-III, which is approximately $95 \%$ homogeneous as judged by disc gel electrophoresis.

isolation, composition, and biologic actions of CTAP-I (from lymphoid tissue) and CTAP-II (from the human HEp-2 tumor cell line) have been reported in detail (514).

Isolation of CTAP-III from human platelets was originally accomplished by assaying for the GAG stimulating activity of fractions generated during the preparative process $(4,14)$. CTAP-III clearly stimulated GAG synthesis in human dermal fibroblast cultures as well as synovial cultures, and the biologic activity was destroyed by thiols, unlike the situation with CTAP:I and -II which were protected by thiols. CTAP-III, isolated on the basis of its GAG stimulating property, was then found to stimulate DNA synthesis in human synovial, cartilage, dermal, and thyroid fibroblasts (15). Platelets aggregated by bovine thrombin were shown to extrude a CTAP-III-like activity into the aqueous suspending medium $(4,16)$, suggesting that this mediator might be released in a physiologic setting like the clotting process. More recent studies show that CTAP-III stimulates formation of chondroitin-4/-6 sulfate, promoting synthesis of the carbon chain as well as incorporation of ${ }^{35} \mathrm{SO}_{4}{ }^{-}$ (17). Of interest is the observation that platelets from patients with rheumatoid arthritis have a quantitative deficit in CTAP-III activity (18).

Others have characterized thrombin releasable platelet proteins utilizing antiheparin activity as an assay method (19). Fractions eluted from a heparin-agarose column were called low affinity platelet factor 4 $\left(\mathrm{LA}-\mathrm{PF}_{4}\right)$ and high affinity platelet factor $4\left(\mathrm{HA}-\mathrm{PF}_{4}\right)$ on the basis of the sodium chloride concentrations required to effect elution from the column. These proteins differed in their antigenic make-up and antiheparin activity and had apparent molecular weights similar to that (11,633 daltons) reported for CTAP-III.

This report provides information concerning the amino acid composition of CTAP-III and the cell spectrum sensitive to the mitogenic action of this mediator. Data concerning the mechanism of action and the effect of selected drugs on the biologic activity of CTAP-III are presented. In addition, data are reported which indicate that CTAP-III is probably identical to low affinity platelet factor $4\left(\mathrm{LA}-\mathrm{PF}_{4}\right)$, an "antiheparin" factor extruded by platelets in the course of platelet release reactions. Further, CTAP-III is similar in some respects to $\beta$-thromboglobulin $(\beta$-TG), also known to be released from platelets during aggregation.

\section{MATERIALS AND METHODS}

\section{Culture methods}

Human synovial membrane specimens were obtained at arthrotomy or amputation, a portion was fixed for histology, and the remainder divided into $1 \mathrm{~mm}^{3}$ fragments and explanted to develop monolayer cultures as reported previously (20). Human dermal and thyroid fibroblast monolayer cultures were generated in a similar manner, while chondrocytes were grown from enzymatically disaggregated cartilage from osteoarthritic human femoral heads removed during total hip arthroplasty (21). Human and mammalian cell lines were also recovered from frozen storage for use in these studies as needed. Routine culture medium for connective tissue cells consisted of $80 \%$ synthetic medium 1066, $10 \%$ fetal calf serum, and $10 \%$ heat inactivated human serum supplemented with Lglutamine, penicillin, streptomycin, and $0.02 M$ Hepes buffer. Human serum was inactivated by incubation at $56^{\circ} \mathrm{C}$ for 1 hour. Cells were counted with a Coulter Model B cell counter (Coulter Electronics, Hialeah, Florida).

Isolation of connective tissue activating peptide-III (CTAP-III) from human platelets. The active platelet principle was extracted into an acid-ethanol medium and subsequently precipitated by acetone as described earlier (4), with several modifications (see Figure 1). Currently, outdated platelets are extracted with stirring in 10 volumes of acid-ethanol (5\% $1.25 \mathrm{~N} \mathrm{HCl}$ : $95 \%$ ethanol) for 1 hour at room temperature followed by centrifugation at $17,300 \mathrm{~g}$ ( 10 minutes, 
$21^{\circ} \mathrm{C}$ ). Precipitation of active material from the supernatant of the acid-ethanol extract was accomplished by adding 3 volumes of acetone at room temperature and allowing the mixture to stand for 1 hour. The precipitate was collected in $1.0 \mathrm{M}$ acetic acid and dialyzed at $6^{\circ} \mathrm{C}$ against 30 volumes of $1.0 \mathrm{M}$ acetic acid containing $3.6 \% \mathrm{NaCl}$. After 16 hours of dialysis, the precipitate that had formed was removed by centrifugation at $5^{\circ} \mathrm{C}$ for 10 minutes at $17,300 \mathrm{~g}$. This supernatant solution was further dialyzed against $0.05 \mathrm{M}$ phosphate buffer, $\mathrm{pH}$ 7.0 , containing $0.15 \mathrm{M} \mathrm{NaCl}$ and any precipitate resulting from this step was removed by centrifugation.

The crude extract was then chromatographed on Sephacryl S-200 $(5 \times 55 \mathrm{~cm})$ equilibrated with phosphate buffered saline. Material emerging from the column in the elution position of cytochrome $\mathrm{C}$ was subsequently further purified by ion exchange chromatography on CM-Sephadex C-50 $(2 \times 6 \mathrm{~cm})$. This column was equilibrated with $0.1 \mathrm{M}$ phosphate buffer, $\mathrm{pH} 6.0$, and the major portion of the CTAP-III was eluted with $0.1 \mathrm{M}$ phosphate, pH 6.0, containing $0.25 \mathrm{M}$ sodium chloride. It was frequently necessary to repeat the gel permeation chromatography and ion exchange chromatography, sometimes including elution from a cation exchanger with a linear salt gradient (4), to achieve preparations homogeneous by SDS disc gel electrophoresis (22) and disc gel electrophoresis in an acid-urea buffer system, (23). The platelet materials may be lyophilized without loss of activity after acetone precipitation and acid-salt precipitation.

Amino acid analysis. A Beckman 120B amino acid analyzer equipped with long path length cells was used and samples were injected from precalibrated loops. Resin (type DCIA) and buffer concentrates (Pico-II) for the single column systems were obtained from Durrum and Pierce respectively. Samples were hydrolyzed, after thorough degassing to $60 \mu$, in $1 \mathrm{ml} \mathrm{HCl}$ with or without $20 \mu \mathrm{l}$ of dimethylsulfoxide for the conversion of half-cystine to cysteic acid (24). Samples were analyzed in duplicate. The data were normalized to give near integral values (residues/mole) for the six most reliable amino acids: aspartic acid, 10.14 and 11.82; glutamic acid, 13.97 and 12.19; glycine, 10.77 and 8.37 ; alanine, 8.10 and 7.85 ; leucine, 7.16 and 10.73; and lysine, 9.72 and 10.97 ; the first figure refers to CTAP-I and the second to CTAP-III. The data for CTAP-II were normalized taking methionine equal to 1.0 .

Free thiol determination. No free thiol could be detected in the absence of guanidinium chloride. Thiol was determined in $0.3 \mathrm{M}$ phosphate buffer, $\mathrm{pH} 7.0$, containing $3.3 \mathrm{M}$ guanidinium chloride and $0.32 \mathrm{mM}$ 5,5'-dithiobis (2-nitrobenzoic acid).

Preparation of antibodies to CTAP-III. Five 18-weekold AJ mice (Jackson Laboratories) were immunized according to the method of Tung et al (25) utilizing $0.2 \mathrm{ml}$ intraperitoneal injections of a 1:9 emulsion of $0.05 M$ sodium acetate, plus $0.3 \mathrm{M} \mathrm{NaCl}, \mathrm{pH} 6.8$, and complete Freunds adjuvant (Miles Laboratories). Three mice were each injected with approximately $100 \mu \mathrm{g}$ CTAP-III in the emulsion on days 0,15 , 22 , and 28 . Ascites fluid was collected twice weekly from day 54 through 83 . Antibody to CTAP-III was also raised in rabbits using multiple injection sites, and a specific immunoabsorbent prepared by a glutaralydehyde crosslinking method (26). The presence of antibodies to CTAP-III in ascitic fluid or serum was determined by the double immunodiffusion method of Ouchterlony (27).
Preparations of low affinity platelet factor $4\left(\mathrm{LA}^{-P_{4}}\right)$, platelet factor $4\left(\mathrm{PF}_{4}\right)$, and $\beta$-thromboglobulin $(\beta$-TG). Dr. Stefan Niewiarowski (Thrombosis Research Center, Temple University, Philadelphia) kindly made available purified preparations of $\mathrm{LA}^{-\mathrm{PF}_{4}}$ (also called low affinity antiheparin factor), high affinity platelet factor $4\left(\mathrm{HA}^{-} \mathrm{PF}_{4}\right.$, also called $\mathrm{PF}_{4}$ ), and rabbit antisera raised against these proteins. Both LA-PF 4 and $\mathrm{PF}_{4}$ were isolated from the supernatant fluid after thrombin aggregation of fresh washed human platelets (28). The authors are grateful to Dr. Duncan S. Pepper (Edinburgh and Southeast Scotland Regional Blood Transfusion Service) for his gifts of $\beta$-thromboglobulin $\left(\beta\right.$-TG)(29) and $\mathrm{PF}_{4}$. Radioimmunoassay of $\beta$-TG and related proteins was performed with commercial reagents (Amersham Corporation).

Preparation of "plasma-serum." Preparation of "plasma-serum" was carried out in a manner similar to that described by Ross (30). This preparation has the protein compostion of serum except that it lacks substances usually contributed by the platelet component of the clotting process. Citrate anticoagulated blood was centrifuged at room temperature for 15 minutes at $1,000 \mathrm{~g}$ and the resulting plasma freed of residual particulate material by centrifugation at $22,000 \mathrm{~g}$ for 30 minutes. Calcium chloride $(1.0 \mathrm{M})$ was then added to a concentration of $20 \mathrm{mM}$, and the plasma preparation incubated for 2 hours at $37^{\circ} \mathrm{C}$. After centrifugation at $22,000 \mathrm{~g}$ for $\mathbf{3 0}$ minutes, the fibrin mass was discarded and the supernatant "plasma-serum" was dialyzed against 40 volumes of Ringer's solution at $4^{\circ} \mathrm{C}$ for 24 hours.

Measurement of tritiated thymidine incorporation into fibroblast DNA. To measure mitogenic activity of test substances, tritiated thymidine (specific activity $51.7 \mathrm{Ci} / \mathrm{mM}$ ) was added to cultures and the radioactivity in cell lysates determined. Cells were plated, $10^{4}$ cells/microtiter well (Falcon, Linbro, or Costar) in a serum-poor medium (Eagle's synthetic medium $97 \%$, fetal calf serum $3 \%$, with penicillin, streptomycin, L-glutamine, and $0.02 M$ Hepes buffer) and incubated in a humidified chamber at $35-37^{\circ} \mathrm{C}$. Test cells were incubated for at least 20 hours with $100 \mu \mathrm{l}$ of medium. Test fractions and vehicles were then added $(5-15 \mu \mathrm{l} /$ well $)$ and incubation was continued for 24 hours when tritiated thymidine $(1.5 \mu \mathrm{Ci} / 15$ $\mu$ l Eagle's synthetic medium/well) was added and incubation resumed for an additional 24 hours. The supernatant medium was aspirated, discarded, and the cell sheets were washed twice, each separately, with phosphate-buffered saline $(\mathrm{pH}$ 7.0), 5\% trichloroacetic acid and absolute methanol. After air drying (at $35^{\circ} \mathrm{C}$ ), the cell sheets were lysed for 1 hour at $37^{\circ} \mathrm{C}$ with $50 \mu \mathrm{l}$ of $0.3 \mathrm{~N}$ sodium hydroxide. Forty microliters of cell lysate were spotted on glass paper (glass fiber filter paper, Whatman grade 934 AH, H. Reeve Angel, Inc., Clifton, New Jersey), dried, and the tritium content quantitated in a Tricarb liquid scintillation spectrometer.

Chemical assay procedure for mediators of connective tissue activation. In typical experiments, $1 \times 10^{6}$ normal synovial cells were plated in T-15 flasks containing $2 \mathrm{ml}$ of standard serum-containing medium. After 4 to 6 hours of incubation at $37^{\circ} \mathrm{C}$, the medium was replaced with $2 \mathrm{ml}$ of Eagle's synthetic medium buffered to pH 7.4 with $0.02 M$ Hepes buffer and supplemented with penicillin, streptomycin, and L-glutamine. Experimental flasks received 0.1 to $0.3 \mathrm{ml}$ of test materials and control flasks received equivalent volumes of an appropriate vehicle. Flasks were incubated at 35 to $37^{\circ} \mathrm{C}$ 
Table 1. Purification of CTAP-III biologic activities

\begin{tabular}{|c|c|c|c|c|c|}
\hline & \multirow[b]{2}{*}{$\begin{array}{c}\text { Total } \\
\text { protein (gm) }\end{array}$} & \multicolumn{2}{|c|}{ Specific activity* } & \multicolumn{2}{|c|}{ Relative specific activity } \\
\hline & & $\begin{array}{c}\text { GAG } \\
\text { stimulation }\end{array}$ & $\begin{array}{c}\text { DNA } \\
\text { stimulation }\end{array}$ & $\begin{array}{c}\text { GAG } \\
\text { stimulation }\end{array}$ & $\begin{array}{l}\text { DNA } \\
\text { stimulation }\end{array}$ \\
\hline $\begin{array}{l}\text { Platelets, } 25 \mathrm{ml} \\
\text { packed volume }\end{array}$ & 7.960 & - & - & - & - \\
\hline $\begin{array}{l}\text { Crude platelet } \\
\text { extract }\end{array}$ & 0.478 & 2.15 & 0.817 & 1.00 & 1.00 \\
\hline $\begin{array}{l}\text { CTAP-III from } \\
\text { CM-Sephadex }\end{array}$ & 0.012 & 6.70 & 2.618 & 3.12 & 3.20 \\
\hline
\end{tabular}

"Specific activity for GAG stimulation was calculated in terms of "CTAP units"/mg of CTAP protein. (See Methods.) DNA stimulating activity was defined in terms of the incremental incorporation of ${ }^{3} \mathrm{H}$-thymidine caused by addition of $1 \%$ human serum to resting cells. This difference was arbitrarily called 100 "DNA stimulating units." Thus, if buffer and $1 \%$ serum treated cultures showed 1,000 CPM and 6,000 CPM, respectively, then 5,000 CPM over buffer control levels would represent 100 "DNA stimulating units." A CTAP-III treated culture with 11,000 CPM would be judged to have 200 units of DNA stimulating activity. These arbitrary units were divided by the CTAP-III protein concentration $(\mathrm{mg} / \mathrm{ml})$ to provide a specific activity value.

for $\mathbf{4 0}$ hours after which total cell protein and total medium hyaluronic acid were determined. Protein was measured by the method of Oyama and Eagle (31). Hyaluronic acid or sulfated glycosaminoglycans were isolated from nonserum-containing medium by using cetylpyridinium chloride without prior proteolysis (3), and uronic acid was determined by a modified carbazole method (32).

The hyaluronic acid formation rate was expressed as $\mu \mathrm{g}$ hyaluronic acid/mg cell protein/24 hours. Experimental and control groups consisted of 2 to 4 flasks and data from each were expressed as mean \pm one standard deviation. Because incremental glycosaminoglycan synthesis by synovial cultures is essentially linear with respect to incubation time and the quantity of CTAP-III added to the cultures, the quantity of CTAP-III "biologic activity" in a sample may be estimated by using the following relation (4):

$$
\mathrm{CTAP}=\frac{A_{1}-A_{0}}{10 \mathrm{~V}}(\text { units } / \mathrm{ml})
$$

where $A_{1}$ represents the rate of hyaluronic acid synthesis, $\mu \mathrm{g}$ of hyaluronate/mg cell protein per 24 hours in stimulated cultures, and $A_{0}$ is the same measurement in control cultures. $V$ is the volume of test sample added to the standard assay cultures. A unit of CTAP-III biologic activity is thus defined as that amount which stimulates a standard synovial culture to augment its hyaluronic acid synthesis rate by $10 \mu \mathrm{g}$ hyaluronic acid $/ \mathrm{mg}$ of cell protein $/ 24$ hours.

Miscellaneous methods. Highly purified CTAP-III was radiolabeled with ${ }^{125}$ I by a method utilizing chloramine- $T$ (33). Isoelectric focusing was performed in $7.5 \%$ polyacrylamide gels containing $2 \%$ ampholytes $(\mathrm{pH} \mathrm{3-10)}$ and 5\% glycerol, and gels were stained with Coomassie Brilliant Blue $\mathbf{R}$.

\section{RESULTS}

Properties of CTAP-III. Previous studies using gel permeation chromatography and SDS gel electrophoresis indicated that the molecular weight of highly purified CTAP-III was approximately 9,300 daltons (4). The molecule was believed to be a cationic protein on the basis of its binding to ion exchange materials and migration characteristics in disc gel electrophoresis. Since 2-mercaptoethanol treatment destroyed both the mitogenic and GAG stimulating activity of the peptide, it was thought that one or more disulfide groups were essential for these biologic activities. Because this treatment did not generate additional protein fragments detectable by disc gel electrophoresis, it was believed that CTAP-III exists as a single polypeptide chain whose conformation was influenced in a critical fashion by intrachain disulfide linkage (4).

Current data confirm the cationic nature of CTAP-III, since in isoelectric focusing studies it appears as a single band with a $\mathrm{pH}_{1}$ of $8.5 \pm 0.4$ (six determinations). CTAP-III also appears to be relatively heat stable, since purified samples dissolved in neutral phosphate buffered saline could be placed in a boiling water bath for 5 minutes with loss of GAG or DNA stimulating properties.

Isolation, chemical characteristics and actions of CTAP-III. The isolation procedures for CTAP-III lead to an increase in specific activity with respect to both the GAG and DNA stimulating actions. As shown in Table 1, extraction of the active principle(s) into an acid-ethanol vehicle results in an initial 16-fold purification, since all of the extractable biologic activity is recovered in $6 \%$ of the original platelet protein. Figure 2 demonstrates that the molecular weight fraction corresponding to cytochrome $C$ is a major constituent of this initial crude extract. The major active fraction after gel permeation chromatography is primarily in the molecular weight range of cytochrome $\mathrm{C}$ (Figure 2). Ion ex- 


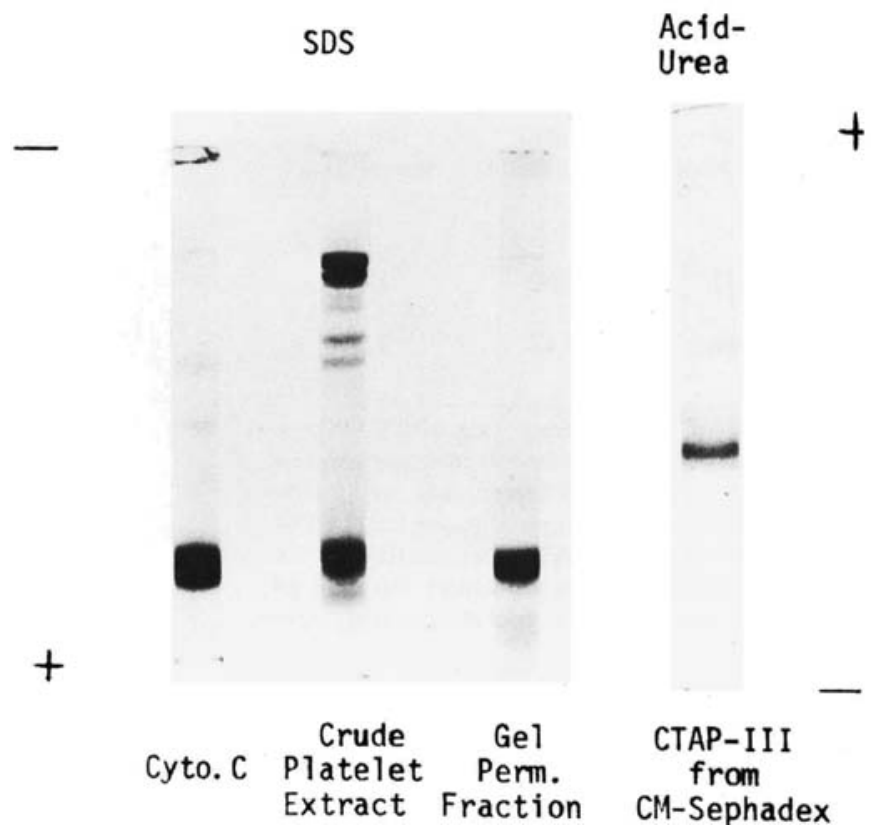

Figure 2. Polyacrylamide gel electrophoresis. The SDS gels indicate that the initial extraction of platelets with acid-ethanol selects heavily in favor of low molecular weight components, and that gel permeation chromatography further simplifies the mixture. The preparation electrophoresed on the acid-urea gel was a $0.25 \mathrm{M} \mathrm{NaCl}$ fraction from a CM-Sephadex column which was then refractionated on a Sephacryl S- 200 column. At least $95 \%$ of the protein resides in a single band. Similar purification may be achieved by eluting from CMSephadex with a linear salt gradient as reported earlier (4).

change chromatography results in an essentially homogeneous preparation as determined by disc gel electrophoresis in an acid-urea system (Figure 2). Further evidence suggesting that the final CTAP-III preparation was homogeneous was obtained by radiolabeling the protein (33) with ${ }^{125} I$ and subjecting this product to electrophoresis in both acid-urea (23) and SDS polyacrylamide gel systems (22). The gels were sliced into consecutive $1.2 \mathrm{~mm}$ segments and their radioactivity was measured with a gamma counter (Automatic Gamma System, Model 1185, Searle Analytic, Inc.). Each gel system showed only one radioactive peak, and in each case it corresponded closely with the position of unlabeled CTAP-III run in parallel gels. The final increases in relative specific activity for the GAG and DNA synthesis stimulating activities are similar (Table $1)$.

The amino acid composition of two preparations of apparently homogeneous CTAP-III was determined and the data are presented in Table 2 . It is clear that CTAP-III resembles CTAP-I and -II with respect to the striking deficiency of aromatic amino acid residues, but differs in that it contained 5 half-cystine residues which are derived from 2 disulfide bonds and a single masked sulfhydryl group. In the presence of a moderate concentration of guanidinium chloride, $0.8 \mathrm{M}$ of thiol was detected per mole of protein. The best fit molecular weight derived from amino acid analysis is 11,633 daltons for CTAP-III and 11,233 for CTAP-I. It should be noted that the molecular weight estimate for CTAP-I has been revised downward from previously published values by utilizing the normalization procedure noted in the Methods section.

Data in Figure 3 show that concentrations of CTAP-III in the range of $29-200 \mathrm{ng} / \mathrm{ml}$ produce easily detectable increments in DNA synthesis in human synovial cell cultures. A half-maximal response was elicited by CTAP-III at $1 \times 10^{-7} M$ concentrations. Similar concentrations appear to be required for the stimulation of increased hyaluronic acid synthesis (measured in terms of uronic acid) and for stimulation of ${ }^{35} \mathrm{SO}_{4}{ }^{-}$incorporation into sulfated glycosaminoglycans.

Efforts to increase the apparent sensitivity of adult human connective tissue cells to the mitogenic action of CTAP-III by prolonging the period of serum deprivation did not materially affect results. Further, the murine 3T3 cell line gave essentially the same data as human cells with respect to its sensitivity to the mitogenic effect of CTAP-III. The enrichment of the final preparation with respect to a specific protein (CTAPIII) is clearly greater than the enhanced (apparent) spe-

Table 2. Amino acid composition of CTAP-I, II, and III

\begin{tabular}{|c|c|c|c|}
\hline \multirow[b]{2}{*}{ Amino acid } & \multicolumn{3}{|c|}{ Residues/mole } \\
\hline & $\begin{array}{c}\text { CTAP-I } \\
\text { (Lymphocyte) }\end{array}$ & $\begin{array}{c}\text { CTAP-II } \\
\left(\mathrm{HE}_{\mathrm{p}-2}\right)\end{array}$ & $\begin{array}{r}\text { CTAP-III } \\
\text { (Platelet) }\end{array}$ \\
\hline Arginine & 4 & 5 & 4 \\
\hline Phenylalanine & 4 & 5 & 1 \\
\hline Tyrosine & 1 & 2 & 2 \\
\hline Leucine & 7 & 10 & 11 \\
\hline Isoleucine & 4 & 4 & 7 \\
\hline Valine & 6 & 9 & 6 \\
\hline Threonine & 6 & 9 & 6 \\
\hline Methionine & 1 & 1 & 1 \\
\hline Proline & 7 & 6 & 4 \\
\hline Half-cystine & 2 & l & 5 \\
\hline Aspartic acid & 10 & 11 & 12 \\
\hline Glutamic acid & 14 & 13 & 12 \\
\hline Lysine & 10 & 8 & 11 \\
\hline Histidine & 2 & 7 & 3 \\
\hline Serine & 8 & 16 & 7 \\
\hline Glycine & 11 & 22 & 8 \\
\hline Alanine & 8 & 15 & 8 \\
\hline Total residues & 105 & 144 & 108 \\
\hline Molecular weight & 11,233 & 14,663 & 11,633 \\
\hline
\end{tabular}




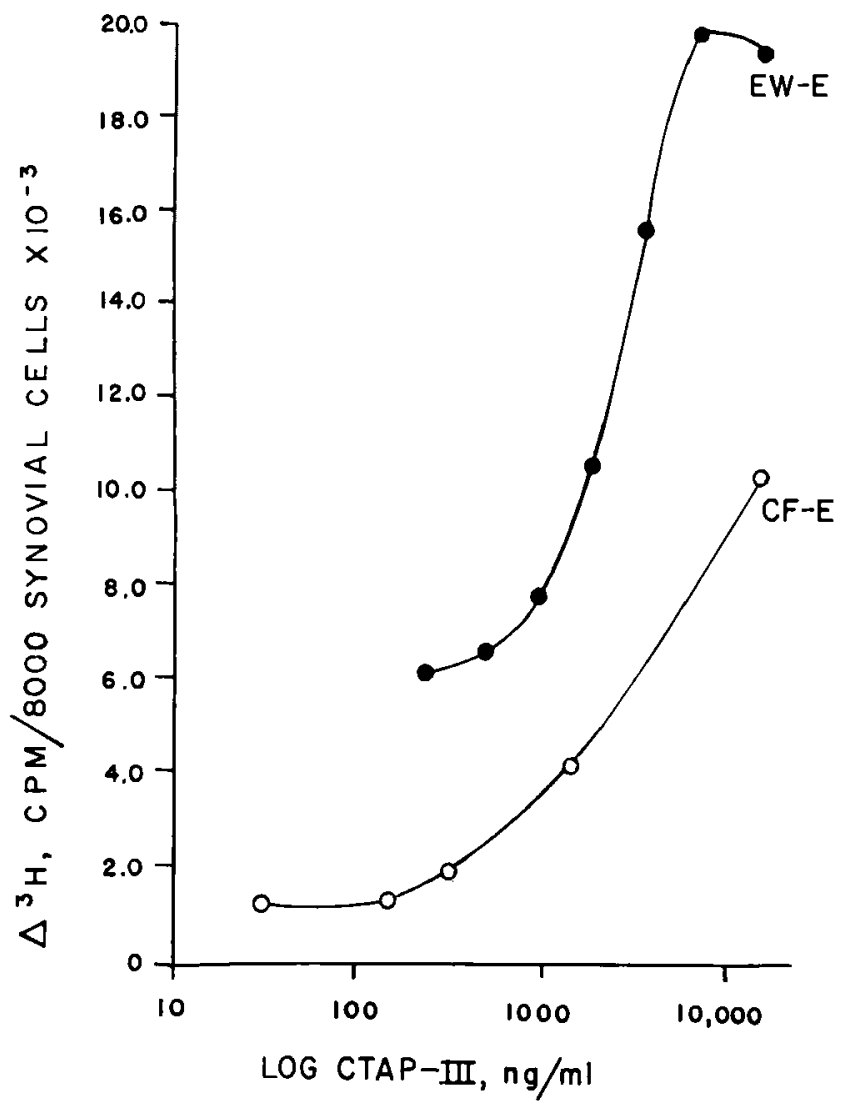

Figure 3. Stimulation of DNA synthesis in human synovial cells by a platelet factor. Both of two normal human synovial cell strains show sensitivity to CTAP-III in $\mathrm{ng} / \mathrm{ml}$ concentrations, but with differing intensity of response.

cific activities with respect to stimulation of DNA and GAG synthesis. Although this apparent dichotomy may be explained by damage to the protein (and consequent loss of specific biologic activity) during the late stages of purification, it should also be pointed out that other (non-CTAP-III) proteins are present in platelets which stimulate GAG and DNA synthesis. There is a higher molecular weight anionic protein, antigenically unlike CTAP-III (to be reported in detail elsewhere), which is systematically removed during the purification of CTAP-III, hence reducing the final specific activity of CTAP-III below what would have been anticipated if all of the GAG and DNA stimulating activities had resided in a single platelet protein species. Further complicating the estimate of "specific activity" of purified CTAP-III, and suggesting that the reported values may well be minimum values, is the fact that the purified protein adsorbs rapidly to glass and other materials. It seems likely that the measured protein concentrations are overestimates of the amount that actually gets into a bioassay after Millipore filter sterilization, storage in glass vials, and pipetting into test culture flasks.

It is pertinent that when platelet preparations are adsorbed on an immunoadsorbent prepared from glutaraldehyde crosslinked rabbit globulins containing antibodies against CTAP-III, the CTAP antigen is removed. Elution of the immunoadsorbent with acid glycine buffer releases antigen (CTAP-III) which has characteristic electrophoretic mobility and GAG and DNA stimulating properties.

CTAP-III as a major serum mitogen for human connective tissue cells. "Plasma-serum" prepared in the absence of platelet aggregation has less than half the capacity of conventional serum to stimulate DNA synthesis in human connective tissue cells. Data in Table 3 demonstrate the reduced mitogenic properties of two separate "plasma-serum" preparations tested on a single connective tissue cell strain, and secondly, show that a second cell strain exhibited the same defective response. The platelet factor could be added back in purified form to the "plasma-serum" or conventional serum with enhancement of DNA-stimulating properties of these sera. The individual plasma proteins tested caused no stimulation of DNA synthesis and, in fact, in some cases appeared to be inhibitory.

Responsive cell spectrum. CTAP-III stimulated DNA synthesis in all of the human connective tissue cell strains that were tested (Table 4). A single adult human arterial endothelial cell strain was also responsive to CTAP-III. On the other hand, DNA synthesis in established human cell lines and in normal human peripheral blood lymphocytes was not stimulated by CTAP-III. While most nonhuman mammalian cell strains and lines usually did not respond to CTAP-III, canine synovial cells and normal rat kidney fibroblasts were exceptions and showed a clear mitogenic response. It was of interest that although both guinea pig and canine lung fibroblasts failed to respond to CTAP-III with increased DNA synthesis, both showed appreciable increases in glycosaminoglycan formation.

Factors related to the mechanism of action of CTAP-III. CTAP-III appears to be very rapidly bound to human connective tissue cells in culture, because cultures exposed for less than 2 minutes to the stimulatory peptide in effective concentrations were clearly committed to accelerated metabolic effort. As shown in Table 5, both PGE 1 and cyclic AMP, in concentrations too small to cause direct stimulation of GAG synthesis, nevertheless substantially potentiate the action of 
Table 3. Effect of serum proteins on connective tissue cell DNA synthesis

\begin{tabular}{|c|c|c|c|}
\hline $\begin{array}{l}\text { Experiment no. } \\
\text { cell strain }\end{array}$ & Additives* & $\begin{array}{l}{\left[{ }^{3} \mathrm{H}\right] \text { Thymidine }} \\
\text { (CPM/8000 cells) }\end{array}$ & Exper/Control \\
\hline \multicolumn{4}{|l|}{1} \\
\hline \multirow[t]{6}{*}{ Synovium (EW) } & Buffer & $1,485 \pm 167$ & - \\
\hline & CTAP-III $(14.6 \mu \mathrm{g} / \mathrm{ml})$ & $18,118 \pm 1,826$ & 12.2 \\
\hline & Plasma-serum (A) & $8,363 \pm 646$ & $5.6+$ \\
\hline & Serum $(A)$ & $18,493 \pm 2,602$ & 12.5 \\
\hline & Plasma-serum + CTAP-III & $24,939 \pm 2,157$ & 16.8 \\
\hline & Serum + CTAP-III & $24,096 \pm 3,515$ & 16.2 \\
\hline \multicolumn{4}{|l|}{2} \\
\hline \multirow[t]{4}{*}{ Synovium (EW) } & Buffer & $1,617 \pm 272$ & - \\
\hline & CTAP-III $(14.6 \mu \mathrm{g} / \mathrm{ml})$ & $19,123 \pm 2,522$ & 11.8 \\
\hline & Plasma-serum (B) & $7,064 \pm 1,635$ & $4.4 t$ \\
\hline & Serum (B) & $24,819 \pm 2,762$ & 15.3 \\
\hline \multicolumn{4}{|l|}{3} \\
\hline \multirow[t]{4}{*}{ Synovium (ORS) } & Buffer & $615 \pm 150$ & - \\
\hline & CTAP-III $(14.6 \mu \mathrm{g} / \mathrm{ml})$ & $18,223 \pm 4,559$ & 29.6 \\
\hline & Plasma-serum (B) & $6,178 \pm 1,274$ & $10.0 \dagger$ \\
\hline & Serum $(B)$ & $20,135 \pm 2,720$ & 32.7 \\
\hline \multicolumn{4}{|l|}{4} \\
\hline \multirow[t]{6}{*}{ Synovium (PR) } & Buffer & $1,179 \pm 145$ & - \\
\hline & CTAP-III $(14.6 \mu \mathrm{g} / \mathrm{ml})$ & $12,834 \pm 1,031$ & 10.9 \\
\hline & Albumin $(108 \mu \mathrm{g} / \mathrm{ml})$ & $512 \pm 136$ & 0.4 \\
\hline & aglobulins $(80.7 \mu \mathrm{g} / \mathrm{ml})$ & $1,030 \pm 203$ & 0.9 \\
\hline & $\beta$ globulins $(33.5 \mu \mathrm{g} / \mathrm{ml})$ & $955 \pm 136$ & 0.8 \\
\hline & Hemoglobin $(127.8 \mu \mathrm{g} / \mathrm{ml})$ & $656 \pm 58$ & 0.6 \\
\hline
\end{tabular}

"Serum and "plasma-serum" prepared from donors "A" and " $B$ " were added, $5 \mu$ per well containing $100 \mu$ of standard assay medium. Serum protein fractions were purchased from Calbiochem, La Jolla, California.

† "Plasma serum" had substantially less capacity to stimulate DNA synthesis than serum prepared from clotted blood in the conventional way.

CTAP-III in causing accelerated GAG formation. Interestingly, both cyclic nucleotides and prostaglandins tended to inhibit rather than potentiate the mitogenic action of CTAP-III. It is noteworthy that much higher

Table 4. Mitogenic effect of CTAP-III on cultured cells

\begin{tabular}{lc}
\hline \multicolumn{1}{c}{ Cells } & Exper/Control* \\
\hline Human connective tissue (strains) & \\
Synovium (7) & $9.5 \pm 5.5$ \\
Cartilage (4) & $6.0 \pm 1.7$ \\
Skin (5) & $11.5 \pm 4.8$ \\
Thyroid (1) & 6.4 \\
Arterial endothelium (1) & 28.4 \\
Human continuous lines & 0.6 \\
CHT (liver) & 1.1 \\
J-III (monocytes) & 0.9 \\
AcH (lymphocytes) & 1.0 \\
HEp (Ca larynx) & \\
Mammalian cell strains & 0.8 \\
Guinea pig lung & 1.0 \\
Dog lung & 3.3 \\
Dog synovium & \\
Mammalian continuous lines & 0.6 \\
BHK (kidney) & 1.9 \\
NRK (kidney) & \\
\hline
\end{tabular}

* Mean \pm 1 standard deviation. concentrations of dibutyryl cyclic AMP and PGE which are known to directly stimulate GAG synthesis $(8,9)$, are also ineffective in stimulating DNA synthesis in these human connective tissue cells. Dibutyryl cyclic

Table 5. Factors modifying CTAP-III regulation of human connective tissue cells

\begin{tabular}{llc}
\hline & \multicolumn{2}{c}{ Synthesis of: $\dagger$} \\
\cline { 2 - 3 } Agents & GAG & DNA \\
\hline Potentiators & & \\
0.01 $\mu \mathrm{g} \mathrm{PGE}_{1}+$ CTAP-III/CTAP-III & 2.9 & 0.73 \\
0.10 $\mu \mathrm{g} \mathrm{PGE}_{\mathrm{I}}+$ CTAP-III/CTAP-III & 3.7 & 0.77 \\
25 $\mu \mathrm{g} \mathrm{Db} \mathrm{cAMP} \mathrm{+}$ & 1.3 & 0.61 \\
CTAP-III/CTAP-III & & \\
50 $\mu \mathrm{g}$ Db cAMP + & 1.7 & 0.63 \\
CTAP-III/CTAP-III & & \\
Inhibitors & & \\
Cyclohex + CTAP-III/CTAP-III & 0.07 & 0.01 \\
ACT-D + CTAP-III/CTAP-III & 0.20 & 0.02 \\
Ara-C + CTAP-III/CTAP-III & 0.86 & 0.02 \\
\hline
\end{tabular}

* Cycloheximide was used in a concentration of $10 \mu \mathrm{g} / \mathrm{ml}$, actinomycin $\mathrm{D}$ in a concentration of $0.1 \mu \mathrm{g} / \mathrm{ml}$, and cytosine arabinoside in a concentration of $10 \mu \mathrm{g} / \mathrm{ml}$.

$\dagger$ Data are recorded as the ratio: experimental/control. 
Table 6. Comparison of autacoid and hormone effects on DNA synthesis in human connective tissue cell cultures*

\begin{tabular}{|c|c|c|c|c|}
\hline Additives & $\begin{array}{c}\text { Hormone } \\
\text { concentration }\end{array}$ & $\begin{array}{c}{ }^{3} \mathrm{H} \text { incorporation, } \\
\mathrm{CPM} / 8000 \text { cells } \\
\text { (mean } \pm \text { ( SD) }\end{array}$ & $\begin{array}{l}\text { Experimental } \\
\text { /control }\end{array}$ & $P \dagger$ \\
\hline \multicolumn{5}{|l|}{ Experiment I } \\
\hline Vehicle & 0 & $1,621 \pm 227$ & - & - \\
\hline CTAP-I & $13.1 \mu \mathrm{g} / \mathrm{ml}$ & $2,939 \pm$ & 1.81 & $<0.001$ \\
\hline CTAP-II & $16.4 \mu \mathrm{g} / \mathrm{ml}$ & $5,239 \pm 901$ & 3.23 & $<0.001$ \\
\hline CTAP-III & $5.1 \mu \mathrm{g} / \mathrm{ml}$ & $18,792 \pm 2,879$ & 11.59 & $<0.001$ \\
\hline \multicolumn{5}{|l|}{ Experiment 2} \\
\hline Vehicle & 0 & $2,045 \pm 342$ & - & - \\
\hline FGF $\ddagger$ & $250.0 \mathrm{ng} / \mathrm{ml}$ & $2,858 \pm 551$ & 1.40 & $<0.05$ \\
\hline CTAP-III & $250.0 \mathrm{ng} / \mathrm{ml}$ & $2,682 \pm 198$ & 1.31 & $<0.05$ \\
\hline & $9.5 \mu \mathrm{g} / \mathrm{ml}$ & $12,009 \pm 2,834$ & 5.87 & $<0.001$ \\
\hline \multicolumn{5}{|l|}{ Experiment 3} \\
\hline Vehicle & 0 & $1,709 \pm 476$ & - & - \\
\hline CTAP-III & $2.4 \mu \mathrm{g} / \mathrm{ml}$ & $30,624 \pm 3,687$ & 17.92 & $<0.001$ \\
\hline TSH§ & $7.7 \mu \mathrm{g} / \mathrm{ml}$ & $6,084 \pm 649$ & 3.56 & $<0.001$ \\
\hline LH§ & $47.6 \mu \mathrm{g} / \mathrm{ml}$ & $8,212 \pm 1,572$ & 4.80 & $<0.001$ \\
\hline \multicolumn{5}{|l|}{ Experiment 4} \\
\hline Vehicle & 0 & $1,645 \pm 220$ & - & - \\
\hline Cortisol & $1.0 \mu \mathrm{g} / \mathrm{ml}$ & $1,176 \pm 516$ & 0.71 & $>0.2$ \\
\hline \multirow[t]{2}{*}{ Insulin } & $10 \mathrm{~m}$ units $/ \mathrm{ml}$ & $3,017 \pm 225$ & 1.83 & $<0.001$ \\
\hline & $100 \mathrm{~m}$ units $/ \mathrm{ml}$ & $7,378 \pm 1,773$ & 4.49 & $<0.001$ \\
\hline TSH & $47.6 \mu \mathrm{g} / \mathrm{ml}$ & $12,067 \pm 772$ & 7.34 & $<0.001$ \\
\hline \multirow[t]{2}{*}{ CTAP-III } & $1.5 \mu \mathrm{g} / \mathrm{ml}$ & $33,949 \pm 5,258$ & 20.64 & $<0.001$ \\
\hline & $3.0 \mu \mathrm{g} / \mathrm{ml}$ & $40,843 \pm 1,679$ & 24.83 & $<0.001$ \\
\hline TSH & $47.6 \mu \mathrm{g} / \mathrm{ml}$ & & & \\
\hline+ & & $7,306 \pm 416$ & 4.44 & $<0.001$ \\
\hline Cortisol & $1.0 \mu \mathrm{g} / \mathrm{ml}$ & & & \\
\hline CTAP-III & $1.5 \mu \mathrm{g} / \mathrm{ml}$ & & & \\
\hline+ & & $33,514 \pm 584$ & 20.37 & $>0.9$ \\
\hline Cortisol & $1.0 \mu \mathrm{g} / \mathrm{ml}$ & & & \\
\hline CTAP-III & $3.0 \mu \mathrm{g} / \mathrm{ml}$ & & & \\
\hline+ & & $38,327 \pm 1,505$ & 23.30 & $>0.05$ \\
\hline Cortisol & $1.0 \mu \mathrm{g} / \mathrm{ml}$ & & & \\
\hline
\end{tabular}

* Experiments 1 and 3 were carried out with normal synovial cell strains from the right and left knees, respectively, and each cell strain was used at the sixth subculture. Experiment 2 utilized cells from another normal human synovial membrane in the fifth trypsin passage; experiment 4 used seventh passage synovial cells.

† Experimental values were compared to the appropriate vehicle values, except for the last three lines of experiment 4, where agonist + cortisol values were compared to the appropriate agonists alone.

$\ddagger$ Fibroblast growth factor, FGF, was purchased from Collaborative Research, Inc., Waltham, Massachusetts.

$\S \mathrm{TSH}$ is thyrotropin, NIH - TSH - B6, bovine. LH is luteinizing hormone, NIE - LH - B8, bovine.

GMP was also ineffective in modifying tritiated thymidine incorporation into DNA in human synovial cultures.

Comparison of mitogenic effects of autacoid and hormones. The marked potency of CTAP-III as a mitogen for human synovial connective tissue cells is recorded in Table 6. CTAP-III $(5.1 \mu \mathrm{g} / \mathrm{ml})$ increased tritiated thymidine incorporation 4 to 6 times more than did CTAP-I and -II, even though the latter were used at higher protein concentrations. Commonly, human CTAP-I and -II exhibit no mitogenic capability against human connective tissue cells. Fibroblast growth factor
(FGF) clearly caused a minor increase in adult human synovial cell DNA synthesis at $250 \mathrm{ng} / \mathrm{ml}$, an effect indistinguishable from that of CTAP-III at the same concentration. This contrasts with the reported stimulation of neonatal human skin fibroblasts by $25 \mathrm{ng} \mathrm{FGF} / \mathrm{ml}$ (34). Both thyrotropin and luteinizing hormone preparations stimulated synovial cell DNA synthesis. In the case of the TSH preparation, the stimulatory action was opposed by the concurrent addition of cortisol to the culture. Cortisol alone did not modify [ $\left.{ }^{3} \mathrm{H}\right]$-thymidine incorporation, and it did not depress or potentiate the action of CTAP-III at the two concentrations tested. In- 


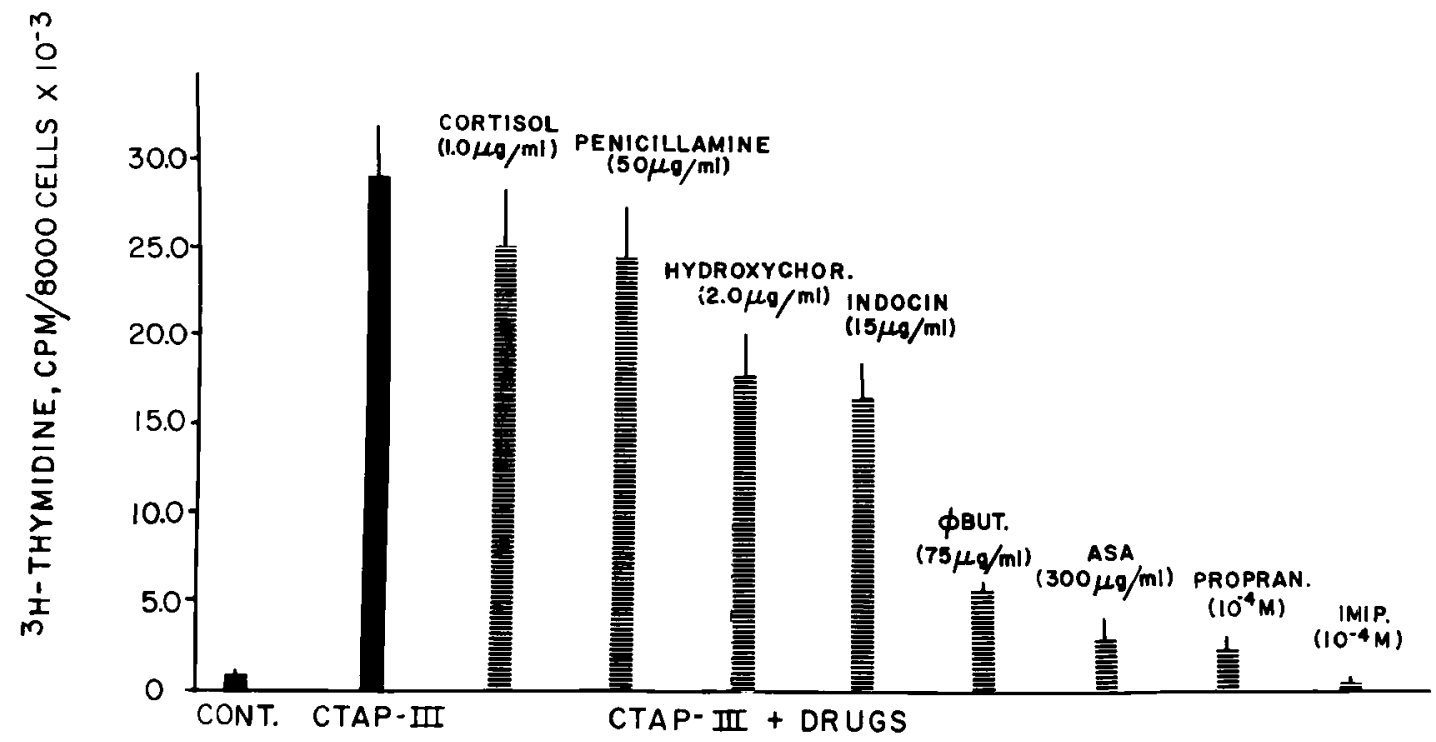

Figure 4. The bars represent the mean $\left[{ }^{3} \mathrm{H}\right]$-thymidine incorporation \pm 1.0 standard deviation. Aspirin, hydroxychloroquine, phenylbutazone, and indomethasone were included in concentrations encountered in clinical practice.

sulin in supraphysiologic concentrations modestly stimulated DNA synthesis.

Drug regulation of CTAP-III enhanced DNA synthesis. The possibility that drugs might modify the capability of CTAP-III to stimulate DNA synthesis in connective tissue cells was explored by using microtiter well cultures. Concentrations of cortisol as high as those

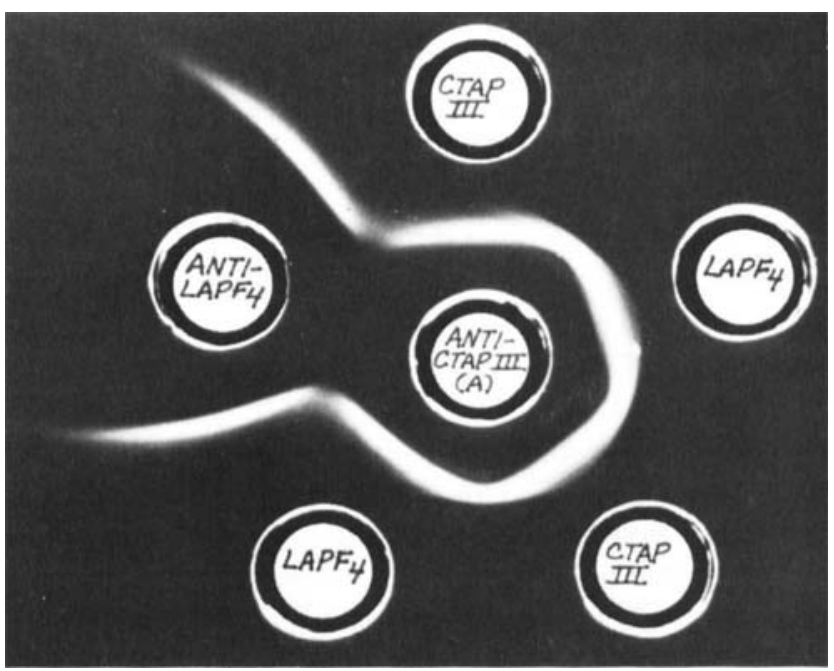

Figure 5. Anti-CTAP-III (prepared in mice) reacts with both CTAPIII and $L A-P F_{4}$ in lines of identity, as does anti-LA-PF 4 (prepared in rabbits). found in Cushing's disease had neither suppressive nor stimulatory effects on CTAP-induced enhancement of DNA synthesis (Figure 4). Cortisol in concentrations ranging from $0.01 \mu \mathrm{g} / \mathrm{ml}$ to $2.0 \mu \mathrm{g} / \mathrm{ml}$ (data not shown) also did not modify CTAP-III-enhanced DNA synthesis. High concentrations of penicillamine caused minor reduction in CTAP-III-stimulated DNA synthesis $(P<0.05)$. Modest suppression of DNA synthesis resulted from the inclusion of hydroxychloroquine and indomethasone at clinically relevant concentrations. Therapeutic concentrations of phenylbutazone and aspirin produced major reductions in CTAP-enhanced DNA synthesis. In several additional experiments (data not shown) it appeared that the marked suspension of DNA synthesis seen with aspirin was primarily achieved at the higher concentrations, since inclusion of the agent at levels corresponding to $15 \mathrm{mg} \%$ was essentially without effect. Significant suppression began at about $20 \mathrm{mg} \%(200 \mu \mathrm{g} / \mathrm{ml})$. The marked suppression of CTAP-III induced DNA synthesis seen with propranolol and imipramine at $10^{-4} \mathrm{M}$ was still present at the $10^{-5} M$, but either absent or very minor at $10^{-6} M$. These data suggest the possibility of using selected drugs to achieve control of precise biochemical actions in circumstances where CTAP-III plays a pathogenetic role. Serotonin, $50 \mu \mathrm{g} / \mathrm{ml}$, and bradykinin, $25 \mu \mathrm{g} / \mathrm{ml}$, had no direct effect in accelerating fibroblast DNA synthesis and clearly did not potentiate the effect of CTAP-III at these concentrations. 


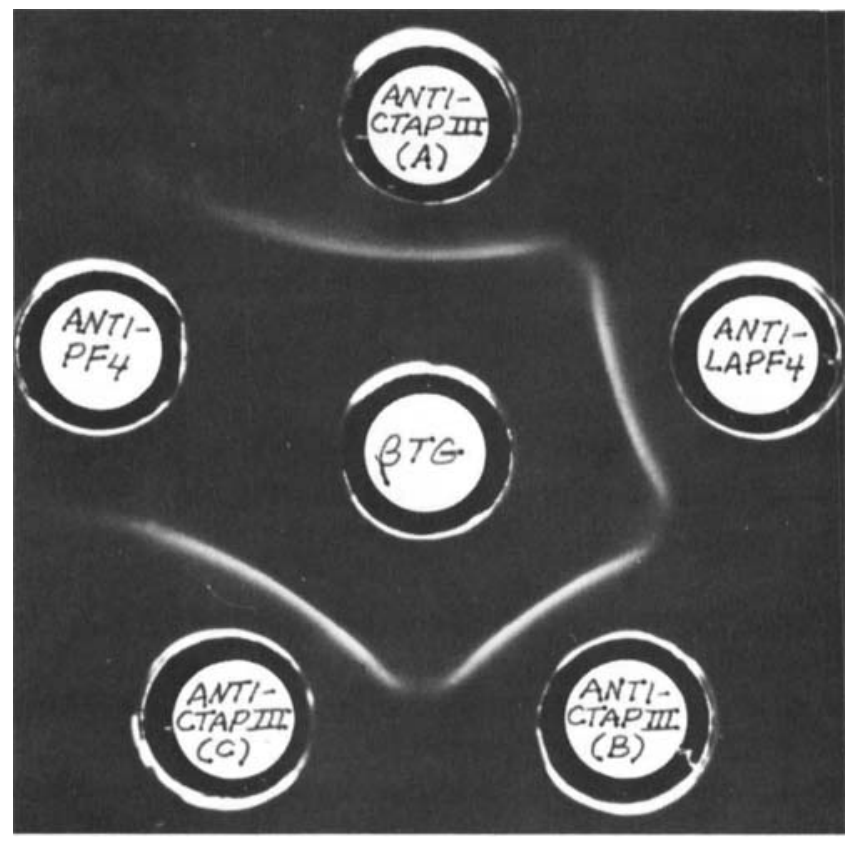

Figure 6. $\beta$-thromboglobulin was recognized by 3 different antisera against CTAP-III and antisera raised against $\mathrm{LA}^{-P_{4}}$, but not by antisera against $\mathrm{PF}_{4}$.

Relationship of CTAP-III to $\mathrm{LA}^{-P F_{4}}$ and $\beta$-TG. CTAP-III and $\mathrm{LA}-\mathrm{PF}_{4}$ have the same electrophoretic mobility in both SDS (22) and acid-urea (23) polyacrylamide disc gel systems, and the amino acid composition of $\mathrm{LA}^{-\mathrm{PF}_{4}}(28)$ is nearly identical to that of CTAP-III shown in Table 2. Similarly, $\beta$-TG resembles CTAP-III in its amino acid composition (28) and electrophoretic mobility in disc gel electrophoretic systems (data not shown). Immunodiffusion studies suggest shared antigenic determinants in CTAP-III, LA-PF ${ }_{4}$, and $\beta$-TG since these peptides give precipitin lines of identity when reacted with mouse anti-CTAP-III or rabbit anti-LA-PF ${ }_{4}$ (Figures 5 and 6). Neither CTAP-I nor CTAP-II reacted with antisera to CTAP-III when tested by immunodiffusion. It was of interest that radioimmunoassay of highly purified $\beta$-TG and CTAP-III, using commerical reagents for measurement of $\beta$-TG, gave concentration values close to those based on protein determination. Bioassay of $\mathrm{LA}-\mathrm{PF}_{4}$ showed that it possessed the same activities known for CTAP-III

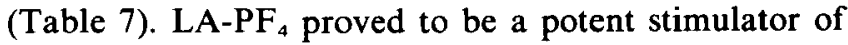
DNA synthesis in synovial cell cultures, to stimulate hyaluronic acid formation in such cultures (measured in terms of uronic acid), and to stimulate incorporation of ${ }^{14} \mathrm{C}$-glucosamine into GAG secreted by these cells. $\beta$ - thromboglobulin caused very modest stimulation of GAG synthesis and barely detectable stimulation of DNA synthesis in human cells.

\section{DISCUSSION}

The amino acid composition of apparently homogeneous preparations of CTAP-III from human platelets was determined. Homogeneity was suggested by a single protein band on SDS and acid-urea disc gel polyacrylamide electrophoresis (4), as well as by the demonstration of near integral values for all amino acid residues. In addition, radioiodination of CTAP-III failed to identify contaminant proteins detectable by SDS or acid-urea gel electrophoresis.

In general, the similarities in the amino acid composition of CTAP-I and -III were more striking than their differences. Even CTAP-II differed primarily in an excessive representation of only four residues (glycine, histidine, serine, and alanine). One of the unusual features of CTAP-III, as predicted by its thiol lability, was the demonstration of two intramolecular disulfide links.

CTAP-III is released from human platelets not only by addition of bovine thrombin, but also in the course of spontaneous blood clotting in vitro. Clearly, the extrusion of CTAP-III from platelets during clotting imparts a major mitogenic principle to the serum. The apparent identity of CTAP-III (isolated from platelets) and $\mathrm{LA}-\mathrm{PF}_{4}$ (isolated from the extracellular milieu after thrombin-induced release) suggests that CTAP-III undergoes no obvious biochemical alteration concomitant with discharge from the platelet.

While CTAP-III was shown to stimulate DNA and GAG synthesis in several kinds of adult human primary connective tissue cell strains, a more extensive survey of cell types is justified. The responsiveness of osteoblasts, mesothelial cells, and embryonic or fetal connective tissue cells is yet unknown. Present data sug-

Table 7. Biologic activities of $\mathrm{LA}^{-\mathrm{PF}_{4}}$

\begin{tabular}{lcc}
\hline Sample & $\begin{array}{c}\left.{ }^{3} \mathrm{H}\right]- \text { Thymidine uptake, } \\
(\mathrm{CPM} / 8000 \text { cells })\end{array}$ & $\begin{array}{c}\text { Hyaluronate synthesis rate } \\
(\mu \mathrm{g} \mathrm{HA} / \mathrm{mg} \text { cell protein } \\
/ 24 \mathrm{hrs})\end{array}$ \\
\hline Buffer & $572 \pm 189$ & $1.0 \pm 0.5$ \\
LA-PF $_{4}^{*}$ & $57,929 \pm 3,372$ & $28.6 \pm 0.7$ \\
& $(16.2 \mu \mathrm{g}$ protein $/ \mathrm{ml})$ & $(148 \mu \mathrm{g}$ protein $/ \mathrm{ml})$ \\
\hline
\end{tabular}

${ }^{*} \mathrm{LA}-\mathrm{PF}_{4}$ was the fraction eluted from a heparin-agarose column with $0.25 M \mathrm{NaCl}$. 
Table 8. Properties of growth factors

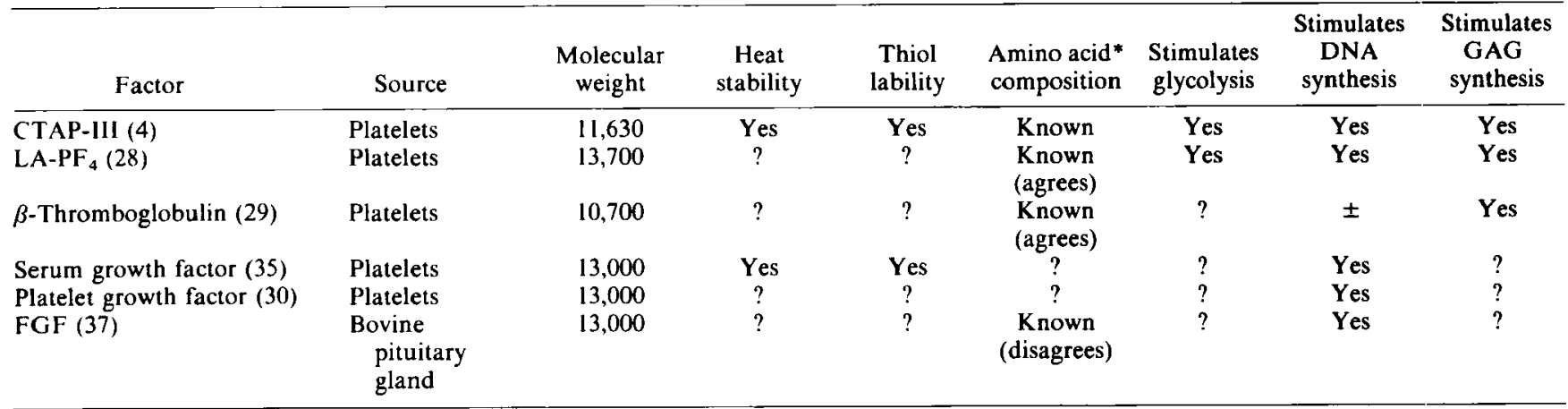

*Where the amino acid composition is known, the term "agrees" relates to similarity in composition to CTAP-III as recorded in Table 1.

gest that human CTAP-III is active in other species, but is usually not mitogenic for established cell lines.

CTAP-III was as stimulatory for adult human synovial cultures as bovine FGF, more potent than TSH, LH, and insulin, and not modified by simultaneous addition of cortisol. Several antirheumatic drugs, particularly aspirin, clearly reduced the mitogenic response to CTAP-III in vitro.

Properties of five platelet derived substances and bovine pituitary FGF are compared in Table 8. CTAP-
III and $\mathrm{LA}-\mathrm{PF}_{4}$, in addition to the tabulated similarities, appear identical on electrophoretic and antigenic bases as well. $\beta$-thromboglobulin is listed in the table because of evidence $(19,29)$ indicating that it shares many molecular characteristics including antigenic determinants and an amino acid compositional pattern with CTAP-

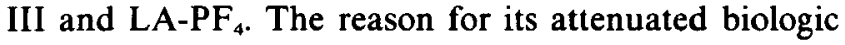
properties is yet unclear. Human "serum growth factor," (35) a platelet derived substance, and primate platelet mitogen (30) resemble CTAP-III and $\mathrm{LA}-\mathrm{PF}_{4}$ as

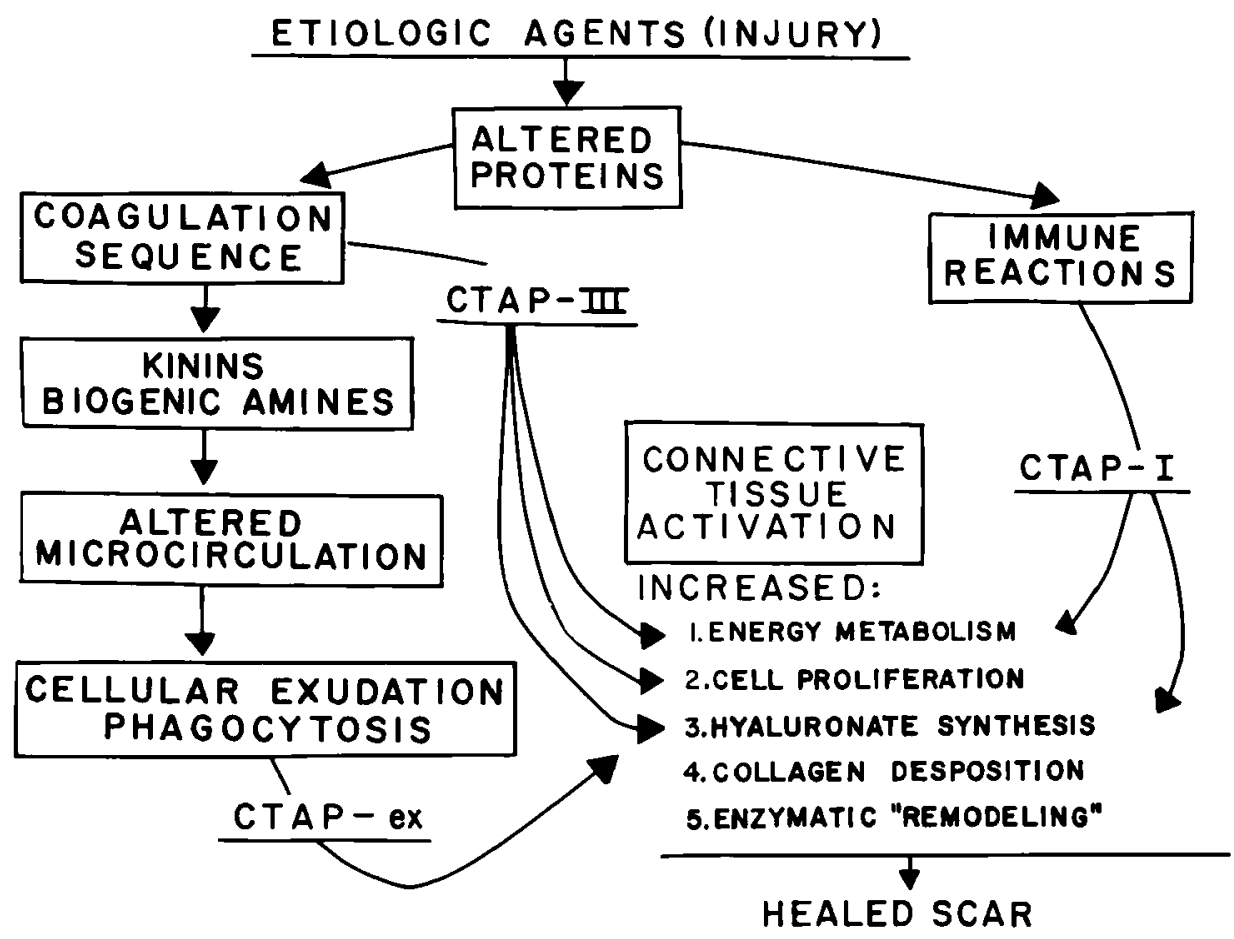

Figure 7. This diagrammatic representation of the inflammatory process highlights the sources of connective tissue activating peptides and their respective actions on connective tissue cells. 
judged by the published characterization of these materials. Clearly, more data are required to establish whether the "serum growth factor" is a different entity than CTAP-III. Indeed, recently reported studies suggest that human platelets may contain more than one mitogenic principle (36). Our experience supports this view. Bovine pituitary FGF is clearly different than CTAP-III in its aspartic acid, proline, half cystine, methionine, isoleucine, and leucine content (37).

The fact that CTAP-III acts on human cells at a somewhat higher concentration than that reported for other platelet preparations raises the possibility that the biologic activity resides in a trace impurity rather than the major protein that has been isolated. However, the co-purification of the GAG and DNA stimulating activity, the sensitivity of both activities to thiols, and their insensitivity to heat all argue that both activities reside in the same molecule. The elution of CTAP-III of high purity possessing GAG and DNA stimulating activity from a specific immunoabsorbent also favors the view that CTAP-III possesses both biologic activities, and that neither is likely to result from trace contamination with an unrecognized agent.

A platelet-derived mediator with the biologic actions shown for CTAP-III might play an important role in inflammatory, atherosclerotic, and thrombotic processes. A schematic view of the inflammatory process is presented in Figure 7. CTAP-III is cast in the role of regulating the transition from the acute (vascular) phase of inflammation to the reparative (proliferative, connective tissue) phase of the inflammatory reaction. "CTAP-ex" refers to a stimulatory principle in polymorphonuclear leukocytes whose characteristics are under study. Implicit in this diagram is the idea that CTAP-III is an autacoid mediator and therefore acts locally on cells near the site of platelet aggregation and release. The relatively high concentrations of CTAP-III $\left(10^{-7} \mathrm{M}\right)$ required to stimulate adult human connective tissue cells are not likely to occur at a great distance from actively secreting platelets. The question of whether CTAP-III is synthesized by the megakaryocyte, or platelet, or merely transported by the platelet after synthesis elsewhere is yet unclear.

\section{REFERENCES}

1. Yaron $\mathrm{M}$, Castor $\mathrm{CW}$ : Leukocyte-connective tissue cell interaction. I. Stimulation of hyaluronate synthesis by live and dead leukocytes. Arthritis Rheum 12:365-373, 1969

2. Castor $\mathrm{CW}$, Yaron M: Leukocyte-connective tissue cell interaction. II. The specificity, duration and mechanism of interaction effects. Arthritis Rheum 12:374-386, 1969

3. Castor CW: Connective tissue activation. I. The nature, specificity, measurement and distribution of connective tissue activating peptide. Arthritis Rheum 14:41-54, 1971

4. Castor CW, Ritchie JC, Scott ME, Whitney SL: Connective tissue activation. XI. Stimulation of glycosaminoglycan and DNA formation by a platelet factor. Arthritis Rheum 20:859-868, 1977

5. Castor CW: Connective tissue activation. III. Observations on the mechanism of action of connective tissue activating peptide. J Lab Clin Med 79:285-301, 1972

6. Castor CW: Connective tissue activation. IV. Regulatory effects of antirheumatic drugs. Arthritis Rheum 15:504514,1972

7. Castor CW, Smith SF, Ritchie JC, Scott ME: Connective tissue activation: mechanism and significance, Biology of the Fibroblast. Proceedings of the Fourth Sigrid Jusélius Foundation Symposium, Turku, Finland, August, 1972. Edited by E Kulonen, J Pikkarainen. London, Academic Press, 1973, pp 483-499

8. Castor CW: Connective tissue activation. VI. The effects of cyclic nucleotides on human synovial cells in vitro. J Lab Clin Med 83:46-55, 1974

9. Castor CW: Connective tissue activation. VII. Evidence supporting a role for prostaglandins and cyclic nucleotides. J Lab Clin Med 85:392-404, 1975

10. Castor CW, Yaron M: Connective tissue activation. VIII. The effects of temperature studied in vitro. Arch Phys Med Rehab 57:1-5, 1976

11. Castor CW: Synovial cell activation induced by a polypeptide mediator, Mechanism of Tissue Injury with Reference to Rheumatoid Arthritis. Edited by RJ Perper. New York, Ann NY Acad Sci 256:304-317, 1975

12. Castor CW: Connective tissue activation. IX. Modification by pharmacologic agents. Arthritis Rheum 18:451560,1975

13. Castor CW, Lewis RB: Connective tissue activation. $\mathrm{X}$. Current studies of the process and its mediators. Scand $J$ Rheumatol 5(suppl 12):41-54, 1975

14. Castor CW, Ritchie JC, Williams CH, Oegema TR: Connective tissue activation: evidence for multiple connective tissue activating peptides. Clin Res 23:527A, 1975

15. Castor CW, Scott ME, Ritchie JC, Whitney SL: Characteristics of a human platelet factor which stimulates DNA and glycosaminoglycan synthesis. Clin Res 24:575A, 1976

16. Castor CW, Scott ME, Ritchie JC, Whitney SL: Connective tissue activation: stimulation of DNA and glycosaminoglycan synthesis by a platelet factor. Arthritis Rheum 20:110, 1977

17. Castor CW, Whitney SL: Connective tissue activation. XIII. Stimulation of sulfated glycosaminoglycan synthesis by human synovial cells. J Lab Clin Med 91:811-821, 1978

18. Smith AF, Castor CW: Connective tissue activation. XII. 
Platelet connective tissue activating factors in patients with rheumatoid arthritis. J Rheumatol 5:2, 177-183, 1978

19. Rucinski B, Niewiarowski S, Budzynski AZ: Separation of two antiheparin proteins secreted by human platelets. Fed Proc 36:4278, 1977

20. Castor CW: Abnormalities of connective tissue cells cultured from patients with rheumatoid arthritis. II. Defective regulation of hyaluronate and collagen formation. $J$ Lab Clin Med 77:65-75, 1971

21. Castor $C W$, Lewis RB: Connective tissue activation. $X$. Current studies of the process and its mediators. Scand $J$ Rheum 5 (suppl 12):41-54, 1975

22. Weber $K$, Osborn $M$ : The reliability of molecular weight determinations by dodecyl sulfate-polyacrylamide gel electrophoresis. J Biol Chem 244:4406-4412, 1969

23. Panyim S, Chalkley E: High resolution acrylamide gel electrophoresis of histones. Arch Biochem Biophys 130:337-346, 1969

24. Spencer RL, Wold F: A new convenient method for estimation of total cystine-cysteine in proteins. Analyt Biochem 32:185-190, 1969

25. Tung, AS, Ju S, Sata S, Nisonoff A: Production of large amounts of antibodies in individual mice. J Immunol $116: 676-681,1976$

26. Avrameas S, Ternynck T: The cross-linking of proteins with glutaraldehyde and its use for the preparation of immunoadsorbents. Immunochem 6:53-66, 1969

27. Ouchterlony $O$ : Diffusion-in-gel methods for immunological analysis. Prog Allergy 5:1-78, 1958

28. Niewiarowski S: Proteins secreted by the platelet. Thromb Hemostasis 38:924-938, 1977
29. Moore S, Pepper DS: Identification and characterization of a platelet specific release product: $\beta$-thromboglobulin, Platelets in Biology and Pathology. Edited by JL Gordon. Elsevier/North Holland Biomedical Press, 1976, p 293

30. Ross R, Glomset J, Kariya B, Harker L: A platelet-dependent serum factor that stimulates the proliferation of arterial smooth muscle cells in vitro. Proc Natl Acad Sci USA 71:1207-1210, 1974

31. Oyama VI, Eagle H: Measurement of cell growth in tissue culture with a phenol reagent (Folin-Ciocalteau). Proc Soc Exp Biol Med 91:305-307, 1956

32. Bitter T, Muir HM: A modified uronic acid carbazole reaction. Analyt Biochem 4:330-334, 1962

33. Greenwood FC, Hunter WM, Glover JS: Preparation of ${ }^{131}$ I-labelled human growth hormone of high specific radioactivity. Biochem J 89:114-123, 1963

34. Gospodarowicz D, Moran JS: Mitogenic effect of fibroblast growth factor on early passage cultures of human and murine fibroblasts. J Cell Biol 66:451-457, 1975

35. Antoniades HN, Scher DC: Radioimmunoassay of a human serum growth factor for Balb/C-3T3 cells: derivation from platelets. Proc Natl Acad Sci USA 74:1973-1977, 1977

36. Heldin CH, Wasteson A, Westermark B: Partial purification and characterization of platelet factors stimulating the multiplication of normal human glial cells. Exp Cell Res 109:429-437, 1977

37. Gospodarowicz D: Purification of a fibroblast growth factor from bovine pituitary. J Biol Chem 250:2515-2520, 1975 